Proceedings

\title{
Analysis of Glacier Area Recession in Vodudahue River Basin and Its Relation with Climate Change ${ }^{\dagger}$
}

\author{
Diana Ramírez \\ Engineering Department, University of Santiago, Usach, Santiago 9170020, Chile; diana.ramirez.p@usach.cl; \\ Tel.: +569-7598-6989 \\ † Presented at the II Congress in Geomatics Engineering, Madrid, Spain, 26-27 June 2019. \\ Published: 17 July 2019
}

\begin{abstract}
This research analyses the glacier recession in the surface area of the Vodudahue river basin glaciers located in Chile, at Comau fjord. A multi-temporal analysis was performed by utilizing Landsat imagery from 1987 to 2017 at a 10-year interval. Also, climate variations regarding temperature and precipitation provided by San Ignacio de Huinay weather station were analyzed. The results show a close relation between the glacier recession in the surface area of identified glaciers and the climate variability in recent years.
\end{abstract}

Keywords: glacier recession; climate change; climate variability

\section{Introduction}

Studies developed in recent years have shown that glacier recession has increased in the last 25 years, principally affecting small glaciers [1]. The year-to-year variability of runoff from glaciers highly depends on ENSO (El Niño-Southern Oscillation) events, which accelerate glacier recession [1].

Chile possesses the biggest glacial surface in South America (around 76\% of glacier mass) [2], which are 18,896 glaciers, according to Chile's General Water Directorate (DGA) [3]. The area of study is located in the Southern Glaciological Zone [3] at Comau Fjord, Los Lagos region; it shows morphoclimatic temperate rainy characteristics [4], where temperate glaciers, mountain glaciers, cirque glaciers, and ice aprons can be found.

\section{Methods and Materials}

The methodology used analyzes in a multi-temporal way the variations of the glacier surface area in the Vodudahue river basin via satellite Landsat 5 TM and Landsat 8 OLI/TIRS images, with a 30-m pixel size, obtained through USGS (United States Geological Survey). Images were searched at a 10-year interval since 1987, using a date as close to the end of estival season in Chile (at the end of March, April, and May) to have the least amount of snow possible to identify the glacier surfaces easier [5], as well as the least cloudiness to have a good visibility of the surface of the area of study [6].

\subsection{Image Correction}

Images have been carefully worked in ENVI 5.3 software, where techniques developed by Chander et al. (2009) [7] were used to transform the spectral information to radiance values. To eliminate scattering and absorption errors, caused by atmospheric suspended particles and molecules, the FLAASH (Fast Line-of-sight Atmospheric Analysis of Spectral Hypercubes) [8] tool was used, which allows for improved lightning conditions caused by factors such as cloudiness. 


\subsection{Identification of the Body of Glaciers}

To automatize the process and combine the images that are part of the area of study, the visual programming language tool Model Builder (available in Arcgis software) was used to create the geoprocessing workflow so a mosaic was obtained, which allowed for identification of glaciers based on band combinations to build glacier polygons for every year of study.

To determine the level of sun exposure and analyze the surface lost by the glaciers, melting speed and the exposure of the same, we proceeded to use a Digital Elevation Model DEM (Digital Elevation Model) of the study area based on level curves, which once exported to the ArcGis platform, were processed using the "Create to TIN" tool (Triangulated irregular network) with which a three-dimensional model of the surface is obtained, and subsequently, the "TIN to Raster" tool was used to obtain the respective DEM. Through the DEM, a solar exposure map was generated using the tool "Aspect" and the exposure of each glacier was determined by observing it from each direction (North, Northeast, Northwest, West, East, South, Southeast, Southwest) [5].

\subsection{Climate Variability Data Correlation}

Meteorological information was obtained from San Ignacio de Huinay, Chaitén, Esquel, Puerto Montt and Bariloche stations, whose information was compiled through the Climatic Explorer of the Climate and Resilience Center (CR2). These stations were considered due to the importance and proximity of the study area, given that they are within a radius of approximately $110 \mathrm{~km}^{2}$. The parameters obtained allowed by simple linear regressions, to project the local behavior estimating it in a general way.

To calculate the accumulated precipitation during cold days the Martens principle [9] was applied to the adiabatic lapse rate, considering that for every $1000 \mathrm{~m}$ upward through the atmosphere temperature decreases $6{ }^{\circ} \mathrm{C}$, establishing that when $11.4{ }^{\circ} \mathrm{C}$ or less are registered in the Huinay station, the basin biggest heights must show temperatures equal or less than $0{ }^{\circ} \mathrm{C}$, thus reaching a freezing point.

\section{Results}

18 glaciers were identified and numbered for a better analysis (Figure 1). Regarding area variation of the identified and analyzed glaciers, recession was found in all cases. The Table 1 shows that Glacier $\mathrm{N}^{\circ} 2$ has the lowest recession, equivalent to $-0.01 \mathrm{~km}^{2}$, and also the lowest mass loss, equivalent to $2.58 \%$ of its initial area. On the contrary, glacier $\mathrm{N}^{\circ} 15$ is the one that showed the biggest recession between 1987-2017, losing $0.48 \mathrm{~km}^{2}$ toward the end of the study, which means a $0.016 \mathrm{~km}^{2}$ loss per year and $88.64 \%$ loss of its original mass. Other glaciers with a considerable recession were $\mathrm{N}^{\circ} 18, \mathrm{~N}^{\circ} 17$, and $\mathrm{N}^{\circ} 11$, with results of $87.69 \%, 53.56 \%$, and $55.84 \%$, respectively.

In relation to the climate variability analysis, Figure 2a indicates that averages of yearly temperatures during the period of the study fluctuate approximately between $9.8^{\circ} \mathrm{C}$ and $10.8{ }^{\circ} \mathrm{C}$ (minimum value during 2000 and maximum during 2008). That is, a variation of $1{ }^{\circ} \mathrm{C}$, approximately. The line shows a positive trend in the average annual temperature values during the study period. 


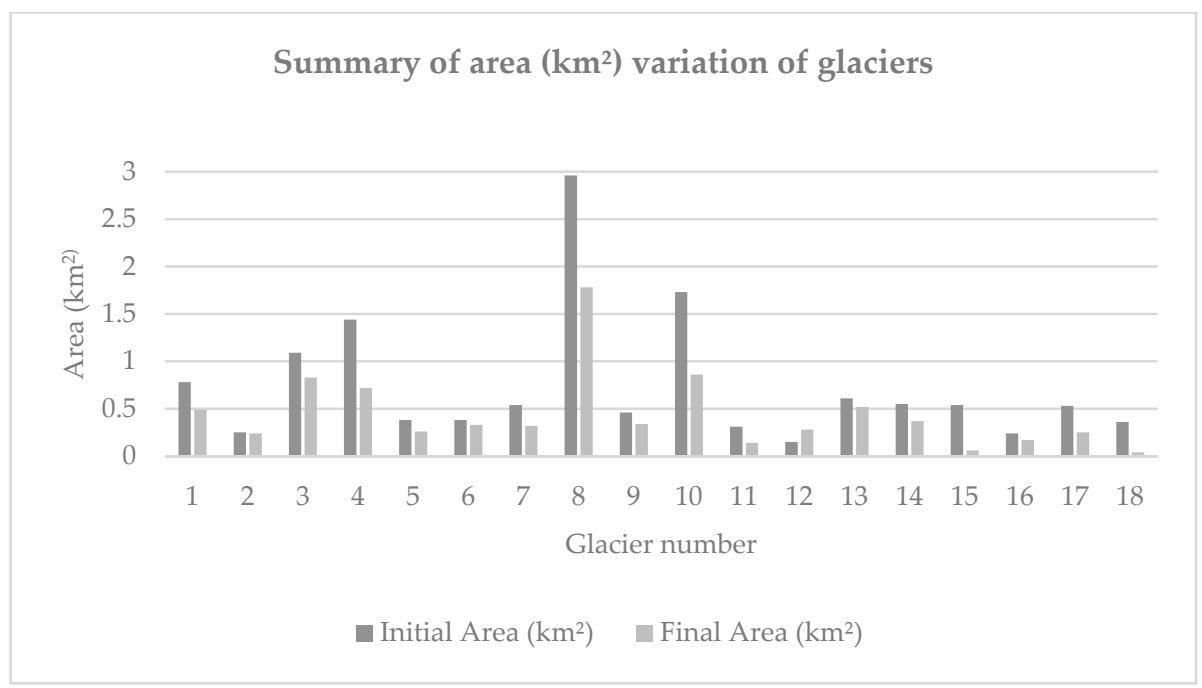

Figure 1. Variation of the area of the glaciers $\left(\mathrm{km}^{2}\right)$ compared to the beginning and end of the study period. Source: Compiled by author.

Regarding precipitation, Figure $2 \mathrm{~b}$ indicates that yearly precipitation averages during the period of the study fluctuate approximately between 4100-4200 mm (minimum value during 2007 and maximum during 2009). That is, a variation of $2500-2600 \mathrm{~mm}$, approximately. The line shows a negative trend in the average annual values of rainfall during the study period.

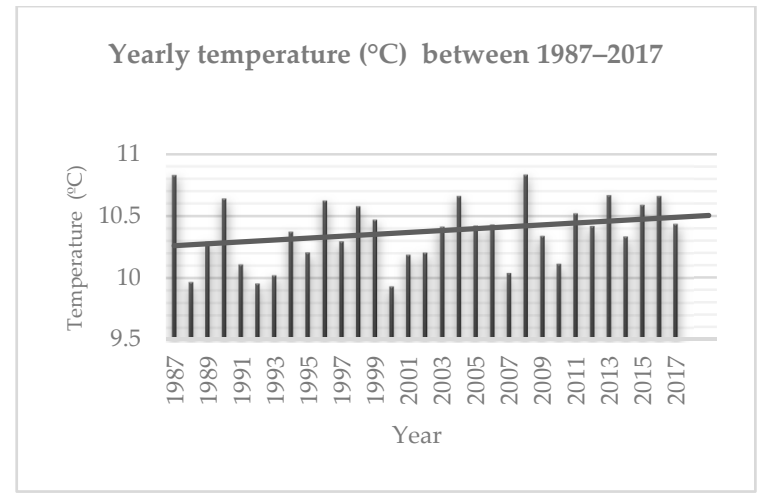

(a)

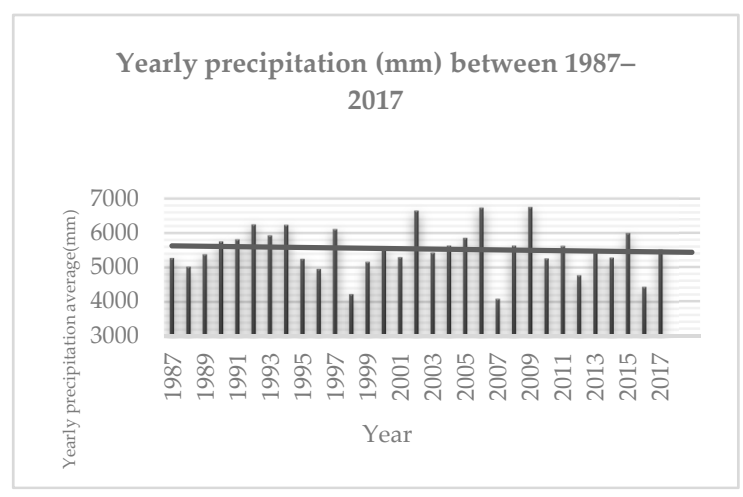

(b)

Figure 2. Temperature variability analysis during the years of the study. (a) Temperature $\left({ }^{\circ} \mathrm{C}\right)$ averages by year. (b) Precipitation ( $\mathrm{mm}$ ) averages by year. Source: Compiled by author.

Additionally, in the course of the interval periods of the study there is a constant precipitation accumulation (possibly in a solid state) during cold days. The minimum value of precipitation registered was approximately $800 \mathrm{~mm}$ in 1987, while the maximum was approximately $1000 \mathrm{~mm}$ in 1998. 
Table 1. Summary of percentage (\%) variation of glaciers.

\begin{tabular}{|c|c|c|c|c|c|c|c|c|c|c|c|c|c|c|c|c|c|c|}
\hline Glacier Number & 1 & 2 & 3 & 4 & 5 & 6 & 7 & 8 & 9 & 10 & 11 & 12 & 13 & 14 & 15 & 16 & 17 & 18 \\
\hline $\begin{array}{c}\text { Area Variation } \\
\left(\mathrm{km}^{2}\right)\end{array}$ & -0.28 & -0.01 & -0.26 & -0.72 & -0.12 & -0.05 & -0.22 & -1.18 & -0.12 & -0.87 & -0.18 & 0.13 & -0.09 & -0.18 & -0.48 & -0.07 & -0.28 & -0.32 \\
\hline$\%$ Variation & -36.56 & -2.58 & -23.63 & -49.98 & -31.79 & -13.11 & -40.58 & -39.99 & -26.2 & -50.48 & -55.84 & 90.78 & -15.49 & -32.71 & -88.64 & -29.23 & -53.56 & -87.69 \\
\hline
\end{tabular}




\section{Conclusions}

Thanks to the methodologies used to establish the variations, applying different corrections to the satellite images, it was possible to determine the areal surface of the glaciers of the Vodudahüe river basin, with a backward movement in the last 30 years.

18 glaciers were identified, every one of them showing a significant recession. By looking at their area variation rates it can be established that a general trend towards a constant increase of recession exists through time. Glacier Vodudahue $\mathrm{N}^{\circ} 14\left(0.060 \mathrm{~km}^{2} /\right.$ year $)$ being the one showing the maximum variation rate and glacier Vodudahue $\mathrm{N}^{\circ} 2$ showing the minimum, according to the surface loss data $\left(-0.01 \mathrm{~km}^{2}\right)$.

The climatic characteristics of the area of study, in terms of temperature and precipitation variations, demonstrate a general trend of temperature rising, with an average increase of $0.3{ }^{\circ} \mathrm{C}$ by decade since 1987. Precipitation decline in cold days is also associated to temperature rising, as well as ENSO event frequency, which is related to an excessive precipitation rising. These climatic variability conditions contribute to the acceleration of the glacier recession in Vodudahue river basin.

Funding: This research was funded by Universidad de Chile through the Fondo Nacional de Desarrollo Científico y Tecnológico (1151087).

Acknowledgments: Special thanks to Mauricio Marín for all his support in the dissemination of the present research.

Conflicts of Interest: Funders did not have any function in the elaboration of this research, recollection, analysis or interpretation of data, paper writing, or decision to publish the results.

\section{References}

1. Programa de las Naciones Unidas para el Medio Ambiente PNUMA (2007). El fin de las cumbres nevadas? Glaciares y cambio climático en la Comunidad Andina. Available online: http://www.pnuma.org/deat1/pdf/ glaciaresandina.pdf (accessed on 14 November 2018).

2. Rivera, A.; Brown, F.; Napoleoni, F.; Muñoz, C.; Vuille, M. Balance de masa glaciar; Ediciones CECs: Valdivia, Chile, 2016; 203p.

3. Dirección General de Aguas DGA. Variaciones recientes de glaciares en Chile, según principales zonas glaciológicas; Realizado por CECs: Valdivia, Chile, 2011.

4. Sarricolea, P.; Herrera, M.; Meseguer, O. Climatic regionalization of continental Chile. J. Maps. 2017, 13, 66-73.

5. Díaz, C. Análisis de variaciones areales de los glaciares ubicados en las cuencas de Vodudahüe y Cahuelmó durante el período 1985-2017. 2018. Available online: http://repositorio.uchile.cl/handle/2250/153015 (accessed on 30 November 2018).

6. Rivera, A.; Acuña, C.; Casassa, G.; Bown, F. Use of remotely sensed and field data to estimate the contribution of Chilean glaciers to eustatic sea-level rise. Ann. Glaciol. 2002, 34, 367-372.

7. Chander, G.; Markham, B.; Helder, D. Summary of current Radiometric Calibration Coeficients for Landsat MSS, TM, ETM+, and EO-1 ALI Sensors. Remote Sens. Environ. 2009, 113, 893-903.

8. Aguilar, H.; Mora, R.; Vargas, C. Metodología para la corrección atmosférica de imágenes Aster, Rapideye, Spot 2 y Landsat 8 con el módulo Flaash del software ENVI. Revista Geográfica De América Central. 2014, 2, 39-59.

9. Martens, B. Thermal Flying: A Guide for Paraglider and Hang Glider Pilots. Thermikwolke 2007, 1, 216. 